\title{
TEKNOLOGI BUDIDAYA LABU MADU DAN PEMANFAATANNYA SEBAGAI PANGAN ALTERNATIF DI DESA PASIGARAN, SUMEDANG, JAWA BARAT
}

\author{
Mira Ariyanti, Erni Suminar \\ Departemen Budidaya Pertanian, Fakultas Pertanian, Universitas Padjadjaran. J1. Raya Bandung- \\ Sumedang km.21, Jatinangor, Jawa Barat, Indonesia \\ E-mail: mira.ariyanti@unpad.ac.id
}

\begin{abstract}
ABSTRAK. Tanaman labu madu belum banyak dikenal oleh masyarakat secara umum. Tanaman ini apabila ditelaah dari segi manfaatnya ternyata berpotensi dijadikan pangan alternatif yang dapat memenuhi asupan gizi masyarakat dengan cara mengolahnya lebih lanjut. Kegiatan pengabdian kepada masyarakat yang diadakan di Desa Pasigaran, Kecamatan Tanjungsari, Kabupaten Sumedang, Jawa Barat bertujuan memperkenalkan dan mendiseminasikan teknik budidaya daya labu madu dan pemanfaatannya sebagai pangan alternatif yang diharapkan dapat menjadi tambahan pendapatan bagi warga setempat. Peserta kegiatan ini kelompok tani Desa Pasigaran. Metode yang digunakan adalah: penjajagan, penyuluhan, pembuatan demplot percontohan pertanaman budidaya labu madu, pemanenan dan pengolahan labu madu, pendampingan. Hasil kegiatan ini adalah terjadi peningkatan wawasan tentang informasi labu madu dan warga sangat antusias untuk melanjutkan ke praktek pengolahan menjadi produk makanan yang sehat dan bergizi.
\end{abstract}

Kata kunci: labu madu; pangan alternatif; teknik budidaya.

ABSTRACT. The butternut squash plant has not been widely known by the general public. When examined from the perspective of its benefits, this plant has the potential to be used as an alternative food that can fulfill people's nutritional intake by further processing it. Community service activities held in Pasigaran Village, Tanjungsari District, Sumedang District, West Java aim to introduce and disseminate butternut squash cultivation techniques and use them as an alternative food which is expected to be additional income for local residents. Participants in this activity were the Pasigaran Village farmer groups. The methods used are exploratory, counseling, making demonstration plots for cultivation, harvesting and processing, and mentoring. The result of this activity was an increase in knowledge about the butternut squash information and the residents were very enthusiastic about continuing to practice processing it into healthy and nutritious food products.

Keywords: butternut squash; alternative food; cultivation techniques.

\section{PENDAHULUAN}

Desa Pasigaran memiliki luas 284 ha yang berlokasi di Kecamatan Tanjungsari Kabupaten Sumedang, terdiri dari enam Rukun Warga (RW) dan 32 Rukun Tetangga (RT). Desa ini berbatasan sebelah utara dengan Kadakajaya, sebelah selatan dengan Margaluyu, sebelah timur berbatasan dengan Sukawangi, dan sebelah barat dengan Sukasari yang berada pada ketinggian sekitar 501-1000 mdpl (meter di atas permukaan laut) dengan suhu rata-rata $25^{\circ} \mathrm{C}$.

Jumlah penduduk desa Pasigaran sekitar 3725 jiwa dimana jumlah laki-laki sekitar 1892 jiwa dan perempuan sekitar 1833 jiwa dengan sebagian besar memiliki mata pencaharian sebagai petani. Jenis usaha lainnya seperti berdagang, PNS, dan wiraswasta lainnya. Banyaknya kaum perempuan usia produktif sebagai petani yang tergabung dalam kelompok wanita tani menjadikan peluang dilakukannya kegiatan mensosialisasikan pengembangan budidaya tanaman labu madu sebagai pangan alternatif. Tujuan kegiatan ini untuk menjalin kerjasama dalam rangka pengembangan komoditas baru yang berpotensi untuk dikembangkan sebagai pangan fungsional. Pangan fungsional adalah pangan olahan yang mengandung satu atau lebih komponen pangan yang berdasarkan kajian ilmiah mempunyai fungsi fisiologis tertentu diluar fungsi dasarnya, terbukti tidak membahayakan dan bermanfaat bagi kesehatan (BPOM RI, 2016). Menurut Kazeem dan Davies (2016), pangan fungsional adalah makanan dan minuman yang mampu mencegah, melindungi dan atau mengobati suatu penyakit dan juga memiliki nilai gizi yang baik.

Di Indonesia sebutan labu madu mungkin belum banyak dikenal karena selama ini dikenal dengan sebutan labu kuning atau waluh. Bentuk fisik labu madu seperti lampu bohlam, apabila dikonsumsi tekstur daging buah terasa lembut dengan rasa yang khas. Kandungan gula buah ini meningkat dengan semakin lamanya waktu penyimpanan (maksimal penyimpanan selama enam bulan). Buah labu madu termasuk buah klimaterik dimana kadar etilen dan aktivitas respirasi meningkat tinggi pada saat buah mulai memasuki fase pematangan buah.

Labu madu termasuk kedalam golongan tanaman semusim hortikultura yang memiliki kandungan nutrisi yang baik untuk kesehatan. Selain itu cita rasa yang manis dengan tekstur daging lembut dan pulen menjadikan jenis labu madu ini banyak disukai konsumen. Labu ini juga mengandung serat (Nurjanah et al., 2020), $\beta$-carotene (Koh and Loh, 2018), carotenoids, phenolic acids, flavonols, minerals and vitamins (Kulczynski and Michalowska, 2019), karotenoid dan polifenol (Matova et al., 2019). 
Karakteristik (ciri khas) tanaman labu kuning adalah tumbuh menjalar, buah berbentuk bulat pipih, lonjong, atau panjang dengan banyak alur (15-30 alur). Panen tanaman labu madu dilakukan ketika tanaman sudah berusia 85-90 hari dengan ciri-ciri tangkai buah bagian pangkal sudah berubah warna yang semula hijau berubah menjadi warna coklat demikian juga buah terlihat berwarrna coklat mengkilap (Anonim, 2019).

Labu madu merupakan pangan lokal yang memiliki bukti ilmiah mampu mengontrol gula darah (Juniati et al., 2017). Hasil penelitian Marbun et al. (2017) menunjukkan bahwa ekstrak ethanolic dari labu madu dapat menurunkan gula darah. Beberapa penelitian pada tikus yang dibuat diabetes menunjukkan ekstrak labu madu memberikan efek hipoglikemik dan bertindak sebagai antidiabetes (Adams et al. 2011; Chang et al. 2014), ekstrak labu madu dan bubuk bijinya dapat memperbaiki sel pankreas dan produksi insulin (Makni et al. 2010; Jin et al. 2013). Menurut Glew et al. (2006) minyak biji labu madu juga mengandung kromium yang diketahui berperan dalam metabolisme karbohidrat dengan penyerapan kromium terbaik.

\section{METODE}

Kegiatan dilakukan pada Bulan Maret 2020 sampai dengan Juni 2020 di Desa Pasigaran Kecamatan Tanjungsari Kabupaten Sumedang, Jawa Barat. Melibatkan perwakilan ibu-ibu kelompok wanita tani dan kader PKK. Metode yang digunakan meliputi dilakukan penjajagan terlebih dahulu (wawancara dengan pihak-pihak terkait) yang dilanjutkan dengan kegiatan penyuluhan (prospek dan manfaat labu madu) pada selang waktu beberapa minggu setelah dilakukan wawancara. Dilanjutkan dengan pelatihan dengan berpedoman pada modul kegiatan yang telah disusun yang diwujudkan dengan pembuatan demplot percontohan budidaya labu madu di lahan mitra tani. Selama kegiatan ini berlangsung dilakukan monitoring berkala disertai dengan pendampingan kegiatan bagi peserta tani yang terlibat. Peserta dilatih bukan hanya sampai teknik budidaya tanaman saja tapi juga sampai dengan tingkat pengolahan menjadi bahan makanan alternatif yang tujuannya bukan hanya untuk menambah pangan keluarga tetapi juga sebagai sumber pendapatan tambahan bagi masyarakat secara lebih luas.

Kegiatan penjajagan, penyuluhan (masih dilakukan secara luring saat itu belum terjadi pandemi) sedangkan pembuatan demplot dilakukan secara langsung di lahan milik warga dengan pendampingan dan konsultasi secara daring (dalam jaringan) yang disebabkan kondisi yang tidak memungkinkan untuk dilakukan tatap muka langsung berhubung adanya pendemi Covid 19 yang sedang melanda. Selain itu dilakukan pendekatan partisipatif kepada masyarakat peserta kegiatan. Pendekatan partisipatif merupakan metode pengamatan suatu fenonema dan menggalinya lebih dalam berdasarkan apa yang sedang terjadi dan berkembang dalam situasi sosial yang jadikan obyek (Darmawan dkk., 2020). Metode pembuatan demplot dilaksanakan secara langsung di lahan percobaan milik warga yang dilakukan budidaya dan pemeliharaan oleh beberapa orang secara bergantian waktunya, sedangkan pengolahan labu madu dilakukan oleh salah seorang yang terampil dalam membuat olahan berbahan baku labu kemudian didokumentasikan dan hasilnya dapat dijadikan contoh jika ada peserta yang akan mencobanya.

\section{HASIL DAN PEMBAHASAN}

Sebelum kegiatan ini dilakukan, tim pelaksana mencari informasi sampai sejauh mana warga mengenal labu madu, hasil menunjukkan bahwa belum pernah ada yang membudidayakan labu madu ini karena ketersediaan benih di toko-toko pertanian sekitar masih sangat terbatas dan masyarakat secara umum belum tertarik untuk membeli labu ini yang memiliki harga jual masih tinggi dan masih tersedia di pasar-pasar modern.

Untuk mensosialisasikan labu madu mulai dari budidaya hingga manfaatnya, maka dilakukan kegiatan penyuluhan dengan memaparkan materimateri terkait labu madu secara langsung karena saat itu belum terjadi pandemi Covid 19, namun kegiatan selanjutnya praktek penanaman dan pemeliharaan pendampingan serta konsultasi dilakukan secara daring. Kegiatan penyuluhan ini diikuti oleh sekitar 20 orang yang terdiri dari para kader masingmasing RW di rumah salah seorang warga mitra. Tujuan kegiatan ini adalah untuk mensosialisasikan, memberikan keterampilan dan minat masyarakat dalam membudidayakan labu madu beserta pengolahan berbagai makanan berbahan baku labu madu. Kegiatan dilakukan dengan metode penyuluhan berupa pemaparan materi dan praktek yang dipandu oleh Dosen Faperta Unpad. Materi yang disampaikan terdiri dari : (1) sosialisasi tentang potensi pengembangan tanaman labu madu (2) teknik budidaya labu madu, (3) pengolahan berbagai olahan berbahan baku labu madu. Dilanjutkan dengan kegiatan praktek secara langsung yang bertujuan untuk meningkatkan keterampilan masyarakat terhadap budidaya labu madu.

Pada saat dilakukan kegiatan ini, peserta tampak antusias dan memperhatikan detail informasi yang disampaikan. Hal tersebut tergambar dengan 
adanya beberapa peserta yang aktif menjawab dengan benar berbagai pertanyaan yang disampaikan pada akhir kegiatan. Pada akhir kegiatan tim penyuluh memberikan bahan penyuluhan berupa hardcopy untuk dijadikan acuan atau pegangan bagi peserta dalam melalukan kegiatan budidaya labu madu

\section{Pembuatan Demplot}

Kegiatan ini dilengkapi dengan pembuatan demplot di lahan milik mitra yang dapat dilihat pada Gambar 1.

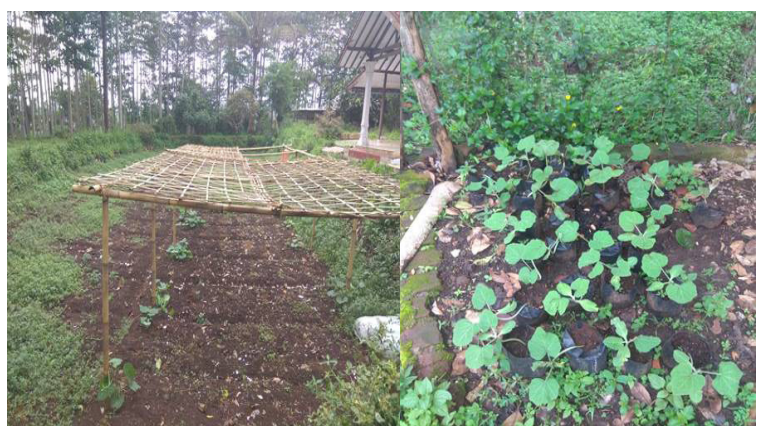

Gambar 1 . Pembibitan dan persiapan lahan pertanaman

Penanaman dilakukan pada dua minggu setelah semai sebanyak 50 tanaman sebagai demplot percontohan bagi warga. Pertanaman labu madu di Desa Pasigaran menunjukkan pertumbuhan yang baik dan mulai produksi buah dengan ukuran yang cukup besar dan banyak (Gambar 2).

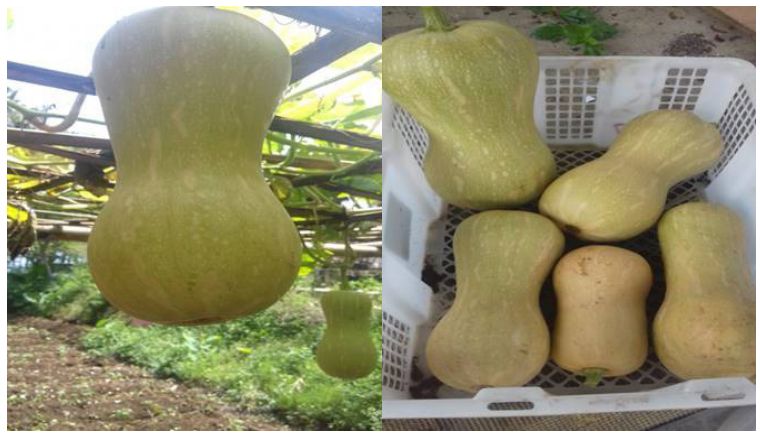

Gambar 4. Hasil Panen Labu Madu

Pemanenan pertama dilakukan pada sekitar 12 minggu sejak penanaman dan labu madu yang dihasilkan telah dicoba dipasarkan ke wilayah komplek-komplek perumahan sekitarnya dengan harga Rp. $10.000,00$ per $\mathrm{kg}$ dan sebagian hasilnya oleh warga diuji coba untuk diolah sebagai bahan pangan alternatif dalam bentuk berbagai cemilan diantaranya : sistik, kue, roti, es krim, puding dengan cita rasa yang khas aroma labu madu (Gambar 5).

\section{Pengenalan Produk Olahan Labu Madu}

Warga melakukan uji coba pengolahan labu madu menjadi bahan cemilan seperti terlihat pada Gambar 3. Beberapa produk olahan tersebut oleh peserta ada yang dikonsumsi sendiri beserta anggota keluarganya dan juga dijual sebagai sumber pendapatan tambahan.

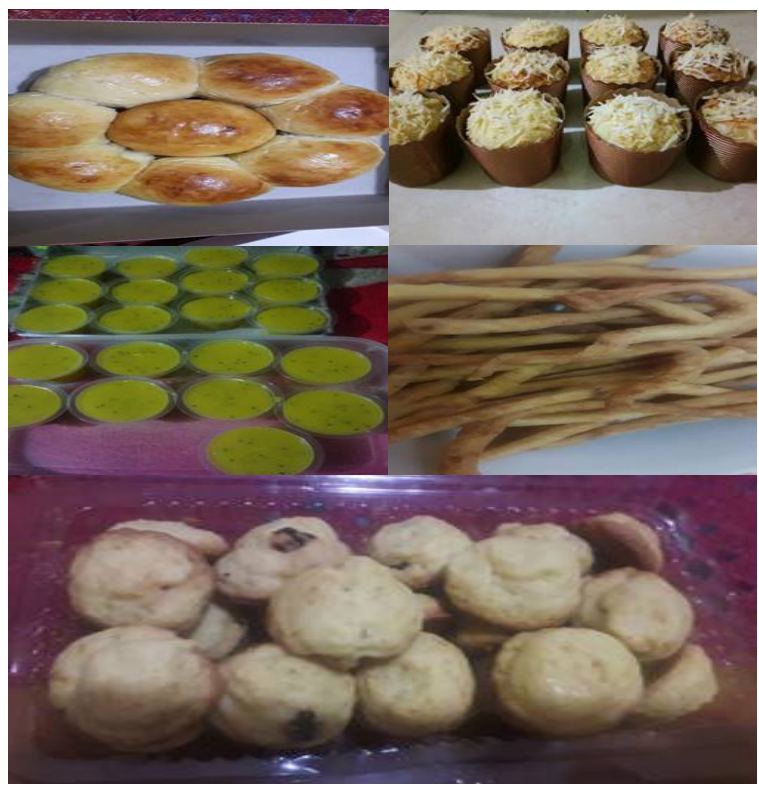

Gambar 3 . Produk olahan labu madu

Labu madu diolah menjadi tepung dan digunakan sebagai bahan baku aneka olahan jadi seperti roti dan kue. Diharapkan Ibu-ibu peserta kegiatan memiliki keinginan untuk dapat mempraktekan cara pengolahan labu madu.

\section{Evaluasi Peserta}

Berdasarkan hasil rekapitulasi data dari pengisian kuosioner, maka dapat dilihat bahwa telah terjadi peningkatan wawasan maupun keterampilan bagi para kader PKK Desa Pasigaran Kecamatan Tanjungsasri Kabupaten Sumedang. Diantara peserta setidaknya saat ini sudah pernah mendengar dan melakukan sendiri tentang labu madu beserta cara budidaya dan pengenalan berbagai produk olahan berbahan baku labu madu sebagai makanan alternatif yang dapat dilihat pada Gambar 4.

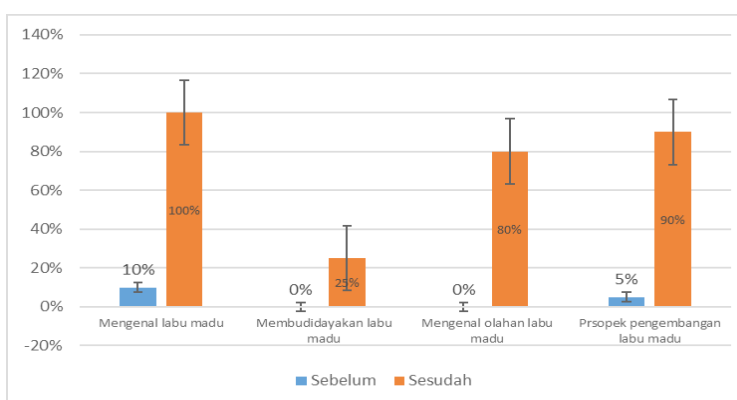

Gambar 6. Rekapitulasi hasil pengisian kuosiner

Pengembangan labu madu merupakan peluang untuk dijadikan sumber pendapatan bagi warga khususnya ibu-ibu rumah tangga yang memiliki lahan pekarangan untuk ditanami labu madu bernilai jual tinggi. Selain itu dengan keterampilan membuat berbagai olahan berbahan baku labu madu maka diharapkan dapat menjadikan labu madu sebagai produk unggulan di daerah tersebut. Oleh karena itu diperlukan wawasan dan keterampilan bagi masyarakat setempat untuk dapat memanfaatkan potensi ini. 


\section{SIMPULAN}

Hasil dari wawancara dengan peserta telah terjadi peningkatan wawasan tentang informasi labu madu dan warga sangat antusian untuk melanjutkan ke praktek pengolahan menjadi produk makanan yang sehat dan bergizi. Kegiatan kerjasama yang dapat dilakukan diantaranya komunikasi dan kegiatan pengabdian yang dapat terus berlanjut hingga saat ini dan tim pelaksana membuka kesempatan bagi peserta yang memerlukan informasi terkait khususnya yang berkaitan dengan labu madu.

\section{DAFTAR PUSTAKA}

Adams, G.G., Imran, S, and Wang, S., Mohammad, A, Kök, M.S, Gray, D.A, Channell, G.A, Morris, G.A, and Harding. S.E. 2011. The hypoglycaemic effect of pumpkins as antidiabetic and functional medicines. $\mathrm{J}$ foodres (44):862- 867.doi:10.1016/j. foodres.2011.03.016.

Anonim. 2019. Cara Budidaya Labu Madu (Butternut pumpkin) di BPP Kecamatan Kalimanah.

[BPOM RI]. Badan Pengawasan Obat dan Makanan RI. 2016. Pengawasan Klaim dalam Label dan Iklan Pangan Olahan. Nomor 13 Tahun 2016. Jakarta: BPOM RI.

Chang C, I., Hsu, C.M, Li, T.S, Huang, S.D, Lin, C.C, Yen, C.H, Chou, C.H, and Cheng. H.L. 2014. Constituents of the stem of Cucurbita moschata exhibit antidiabetic activities through multiple mechanisms. J JFF 6(10):260-273. doi:10.1016/j.jff.2014.06.017.

Darmawan, I., Haq, M.D, dan Egaputri. K.D. 2020. Edukasi mengenai sampah dan sanitasi lingkungan di Desa Cintamulya, Kecamatan Jatinangor, Kabupaten Sumedang. Dharmakarya. 9 (3) 163-166.

Glew, R.H., Glew, R.S., Chuang LT., Huang, Y.S., Millson, M., Constans, D, and Vanderjagt. D.L. 2006. Amino acid, mineral and fatty acid content of pumpkin seeds (Cucurbita spp.) and Cyperus esculentus nuts in The Republic of Niger. Plant Foods for Human Nutrition 61(2):49-54.doi: 10.1007/s11130-006- 0010.

Jin, H., Zhang, Y.J., Jiang, J.X., Zhu, L.Y., Chen, P., Li J, and Yao. H.Y. 2013. Studies on the extraction of pumpkin components and their biological effects on blood glucose of diabetic mice. Journal of food and drug analysis. 21(2): 184-189. doi: 10.1016/j.jfda.2013.05.009.

Juniati, D., Setiawan, B., Anwar, F, dan Muhandri. T. 2017. Komponen gizi, aktivitas antioksidan dan karakteristik sensori bubuk fungsional labu kuning (Cucurbita moschata) dan tempe. J. Gizi Pangan 12(2):109-116.

Kazeem, M.I. and Davies.T.C. 2016. Anti-diabetic functional foods as sources of insulin secreting, insulin sensitizing and insulin mimetic agents. Journal of Functional Foods. 20:122-138. doi:10.1016/j.jff.2015.10.013.

Koh, S.H, and Loh. S.P. 2018. In vitro bioaccessibility of B-carotene in pumpkin and butternut squash subjected to different cooking methods. IFJR 25(1): 188-195.

Kulczynski, B. and Michałowska. A.G. 2019. The profile of secondary metabolites and other bioactive compounds in Cucurbita pepo L. and Cucurbita moschata pumpkin cultivars. Molecules 24: 2945.

Makni, M., Sefi, M., Fetoui, H., Garoui, E.M., Gargouri, N.K., Boudawara, T, and Zeghal. N. 2010. Flax and pumpkin seeds mixture ameliorates diabetic nephropathy in rats. Food Chem Toxicol 48(8-9):2407-2412. doi: 10.1016/j. fct.2010.05.079.

Matova, A, Hegedüsová, A., Andrejiová, A., Kuzmová, P., Farkaš, J, and Timoracká. M. 2019. The influence of genotype and storage condition on the content of selected bioactive substances in the fruit of pumpkin (Cucurbita moschata Duch.). J Microbiol Biotech Food Sci. Vol. 9 (2): 288-292.

Marbun N., Sitorus,P. dan Sinaga. S.M. 2018. Antidiabetic effects of pumpkin (Cucurbita moschata Durch) flesh and seeds extracts in Streptozotocin induced mice. Asian J Pharm Clin Res. Vol 11(2): 91-93.

Nurjanah H., Setiawan, B. dan Roosita.K. 2020. Potensi Labu kuning (Cucurbita moschata) sebagai makanan tinggi serat dalam bentuk cair. Indonesian.J. Human Nutrition. Vol. 7(1):54-68. 